\title{
KS. LUDWIK GRZEBIEŃ SI (1939-2020) - UCZEŃ I ASYSTENT NAUKOWY KSIĘDZA PROFESORA STANISŁAWA LIBROWSKIEGO
}

\begin{abstract}
Streszczenie
Jezuita ks. Ludwik Grzebień był studentem, a następnie asystentem naukowym ks. prof. Stanisława Librowskiego. Ich współpraca rozpoczęła się w 1968 r., kiedy opublikowane zostały prace naukowe ks. L. Grzebienia. W tym samym roku podjął studia w Instytucie Historii Kościoła, uczęszczając na seminariom ks. S. Librowskiego. W 1970 r. ks. L. Grzebień przedstawił pracę magisterską pt. Biblioteka biskupa Hieronima Rozrażewskiego (1542-1600). Już po roku od uzyskania magisterium (1971) złożył dysertację pt. Organizacja bibliotek jezuickich $w$ Polsce od XVI do XVIII wieku. Obydwie parce naukowe uzyskały bardzo dobre oceny recenzentów. Po obronie doktoratu w 1972 r. ks. S. Librowski zaproponował ks. L. Grzebieniowi pracę asystenta naukowego w Katedrze Nauk Pomocniczych Historii i Metodologii Historii. W czasie pracy naukowo-badawczej w KUL odznaczył się dużą pracowitością naukową. W roku akademickim 1972/1973 opublikował pięć artykułów naukowych. W sierpniu 1973 r. ks. L. Grzebień wyjechał do Anglii na kurs językowy, kwerendy archiwalne oraz w celu odbycia kolejnego etapu formacji zakonnej. Z pobytu tego nie wrócił do pracy w KUL, poświęcając się realizacji swoich planów naukowych związanych jednak z zakonem jezuitów.

Słowa kluczowe: ks. Ludwik Grzebień; ks. Stanisław Librowski; Ignatianum; jezuici; Katolicki Uniwersytet Lubelski
\end{abstract}

Jezuita ks. Ludwik Grzebień był jednym z najwybitniejszych polskich historyków Kościoła. Przez większość swojego życia zakonnego związany był z jezuickim ośrodkiem naukowym w Krakowie, który współtworzył. W swoim śro-

\footnotetext{
* Artur Hamryszczak - dr historii; asystent naukowy w Ośrodku Archiwów, Bibliotek i Muzeów Kościelnych KUL; e-mail: artur.hamryszczak@kul.pl

https://orcid.org/0000-0002-2578-9971
} 
dowisku zawsze podkreślał, że solidną formację naukową zawdzięczał nie tylko zakonowi jezuitów, ale i Katolickiemu Uniwersytetowi Lubelskiemu, gdzie pod kierunkiem ks. prof. Stanisława Librowskiego uzyskał magisterium i doktorat z historii Kościoła ${ }^{1}$.

W dotychczasowych publikacjach opisujących życie ks. L. Grzebienia brakuje uwypuklenia czasu jego studiów uniwersyteckich na KUL oraz pracy jako asystenta ks. prof. S. Librowskiego w Katedrze Nauk Pomocniczych i Metodologii Historii KUL. Czas ten, który choć krótki (1968-1973), zaważył na jego dalszych losach naukowych ${ }^{2}$ To w czasie studiów i pracy na KUL wykrystalizowały się jego zainteresowania badawcze oraz nabył on pod okiem ks. prof. S. Librowskiego konieczne umiejętności naukowe. Prezentowany tekst ma uzupełnić lukę w dotychczasowych badaniach biograficznych nad życiem i działalnością tego wybitnego historyka Kościoła. W artykule wykorzystano głównie źródła z Archiwum Uniwersyteckiego KUL ${ }^{3}$ oraz wspomnienia ks. L. Grzebienia ${ }^{4}$.

Ks. Ludwik Grzebień urodził się 15 sierpnia 1939 r. w podkarpackiej wsi Tułkowice koło Strzyżowa, w rodzinie chłopskiej. W 1956 r. po ukończeniu dwóch klas gimnazjum w Czudcu wstąpił do zakonu jezuitów i rozpoczął nowicjat w Starej Wsi. Po jego ukończeniu kontynuował naukę w szkole średniej uwieńczoną uzyskaniem świadectwa dojrzałości w $1961 \mathrm{r}$. w Kaliszu. W tym samym roku rozpoczął studia na Wydziale Filozoficznym Towarzystwa Jezusowego w Krakowie (1951-1964), które kontynuował na Wydziale Teologicznym „Bobolanum” w Warszawie. W 1967 r. przyjął święcenia kapłańskie z rąk Stefana kard. Wyszyńskiego. Był uczestnikiem studiów doktoranckich z historii Kościoła w Katolickim Uniwersytecie Lubelskim, gdzie pod kierunkiem ks. prof. Stanisława Librowskiego przygotował rozprawę dotyczącą organizacji jezuickich bibliotek w Rzeczpospolitej przedrozbiorowej, uzyskując w 1972 r. stopień naukowy doktora. W 1978 r. przeprowadził na Akademii Teologii Katolickiej kolokwium habilitacyjne na podstawie dorobku naukowego i pracy Pionierski trud misjonarzy stowiańskich 1881-1969. W 1990 r. został profesorem nadzwyczajnym historii Kościoła, a w 1999 r. zwyczajnym. Ks. L. Grzebień pracował jako asystent w KUL (1972-1973), wykładowca w ATK (1979-1982), na Wydziale Filozoficznym To-

${ }^{1}$ S. Cieślak, Jubileusz o. Ludwika Grzebienia SJ, „Biuletyn Historii Wychowania”, 26 (2010) s. $124-125$.

${ }^{2}$ R. Terlecki, Pasja historyka. Ojca Ludwika Grzebienia życie i praca, w: Pamięć wieków ksztattuje potomność. Księga jubileuszowa dedykowana Księdzu Profesorowi Ludwikowi Grzebieniowi SJ z okazji 70. Urodzin, red. A.P. Bieś, B. Topij-Stempińska, Kraków 2010, s. 17-22; Cieślak, Jubileusz o. Ludwika Grzebienia SJ, s. 121-130; Jezuicka ars historica: prace ofiarowane Księdzu Profesorowi Ludwikowi Grzebieniowi SJ, red. M. Inglot, S. Obirek, Kraków 2001; S. Cieślak SJ, Odszedt do Pana śp. o. Ludwik Grzebień SJ - wspomnienie, https://jezuici.pl/2020/03/odszedl-do-pana-sp-o-ludwik-grzebien-sj/ (dostęp: 02.04.2020); tenże, Jubileusz o. Ludwika Grzebienia SJ, s. 124-125; Grzebień Ludwik, https://www.jezuici.krakow.pl/cgi-bin/rjbo?b=enc\&q=GRZEBIEN\&f=1 (dostęp: 02.04.2020).

${ }^{3}$ Archiwum Uniwersyteckie KUL (dalej: AUKUL), sygn. A-1148, Referat Personalny, Akta osobowe pracowników, Grzebień Ludwik ks. (1972-1974).

${ }^{4}$ L. Grzebień, Mistrz nad mistrzami - ksiądz profesor Stanisław Librowski, w: Ksiadz Stanisław Librowski. Archiwista, historyk Kościoła i dydaktyk, red. W. Żurek, D. Kiper, Lublin 2015, s. 69-75. 
warzystwa Jezusowego w Krakowie (1985-1999) oraz Papieskiej Akademii Teologicznej w Krakowie (1989-2004). Był dziekanem jezuickiego Wydziału Teologicznego w latach 1988-1994, a w latach 2004-2010 rektorem Wyższej Szkoły Filozoficzno-Teologicznej „Ignatianum” w Krakowie. Pełnił również funkcję dyrektora Biblioteki Naukowej Księży Jezuitów (1988-2010) i Archiwum Prowincji Małopolskiej Księży Jezuitów w Krakowie (1988-2010). Dorobek naukowy ks. L. Grzebienia liczy ponad 1300 publikacji, w tym 30 książek. Wypromował siedmiu doktorów. Jego zainteresowania badawcze skupiały się wokół archiwistyki, biografistyki, dziejów kultury i szkolnictwa jezuickiego, bibliotek zakonnych, historii misji katolickich oraz emigracji polskiej ${ }^{5}$.

Ks. L. Grzebień nawiązał współpracę naukową z ks. prof. S. Librowskim ${ }^{6}$ w 1968 r. dzięki protekcji ks. prof. Mariana Żurowskiego SJ7 z Wydziału Teologicznego „Bobolanum” w Warszawie, pod kierunkiem którego napisał dwie prace naukowe. Promotor zarekomendował ks. S. Librowskiemu druk tych dzieł na łamach półrocznika „Archiwa, Biblioteki i Muzea Kościelne”. Redaktor naczelny nie wniósł żadnych zastrzeżeń, w związku z czym wspomniane prace ukazały się dru-

${ }^{5}$ J. Walkusz, Sekcja Historii Kościoła w Polsce 1964-2014, Pelplin 2016, s. 155-156; Terlecki, Pasja historyka. Ojca Ludwika Grzebienia życie i praca, s. 17-22.

${ }^{6}$ Stanisław Librowski (1914-2002). W 1931 r. wstąpił do Wyższego Seminarium Duchownego we Włocławku. Po wybuchu II wojny światowej został aresztowany wraz z wszystkimi duchownymi Włocławka i uwieziony w obozie w Dachau. Po wyzwoleniu obozu 29 IV 1945 r. udał się do Francji gdzie po ukończeniu wykształcenia teologicznego, otrzymał święcenia kapłańskie. W 1946 r. powrócił do Włocławka. W 1947 r. został mianowany kierownikiem Archiwum Diecezjalnego we Włocławku. W latach 1946-1948 studiował historię w Uniwersytecie Warszawskim. W 1948 r. uzyskał tytuł magistra teologii w zakresie historii Kościoła na podstawie pracy Kapituła katedralna we Włocławku, napisanej na seminarium ks. prof. Zdzisława Obertyńskiego. W 1951 r. uzyskał tytuł doktora na podstawie pracy Hieronim Rozdrażewski, biskup kujawski i pomorski. Od 1958 r. podjął pracę na KUL, m.in. w Ośrodku ABMK, a po uzyskaniu habilitacji kierował Katedrą Metodologii i Nauk Pomocniczych Historii Kościoła. W 1964/1965 uzyskał habilitację na Uniwersytecie Warszawskim, przedstawiając rozprawę Wizytacje diecezji kujawskiej i pomorskiej. W 1970 r. Ministerstwo Oświaty i Szkolnictwa Wyższego potwierdziło tytuł profesora nadzwyczajnego, a w 1975 r. zwyczajnego. M. Zahajkiewicz, Librowski Stanisław, w: Encyklopedia katolicka, t. 10, red. A. Szostek, Lublin 2004, kol. 985-986; tenże, Ksiądz profesor dr hab. Stanisław Librowski (1914-2002), badacz przeszłości i uczony zastużony dla archiwistyki kościelnej, „Archiwa, Biblioteki i Muzea Kościelne” (dalej: ABMK), 79 (2003) s. 13-18; W. Kujawski, Ks. prof. Stanisław Librowski. Archiwista, historyk, redaktor, „Studia Włocławskie” (dalej: SW), 2 (1999) s. 7-17; M. Dębowska, Wkład księdza profesora Stanisława Librowskiego w powstanie, organizację i realizację zadań statutowych Ośrodka Archiwów Bibliotek i Muzeów Kościelnych, SW, 10 (2007) s. 53-61.

${ }^{7}$ Marian Aleksander Żurowski SI (1923-1988) - jezuita, profesor prawa kanonicznego. Uzyskał doktorat w 1960 r. na rzymskim Uniwersytecie Gregoriańskim. Od 1960 r. wykładowca na jezuickim Wydziale Teologicznym „Bobolanum” w Warszawie oraz na Wydziale Prawa Kanonicznego Akademii Teologii Katolickiej. W 1966 r. uzyskał habilitację, a w 1973 r. profesurę nadzwyczajną. W latach 1969-1974 r. gościnnie wykładał na Uniwersytecie Gregoriańskim. Dziekan „Bobolanum” w latach 1967-1971, prodziekan (1969-1972) i dziekan (1972-1975) Wydziału Prawa Kanonicznego ATK. Był promotorem 80 prac magisterskich i 8 doktoratów. Przynależał do międzynarodowych stowarzyszeń naukowych. Był autorem podręczników z prawa kanonicznego. E. Sztafrowski, Śp. ks. prof. Marian Aleksander Żurowski SJ, „Prawo Kanoniczne”, 34 (1991) nr 1-2, s. 5-7. 
kiem ${ }^{8}$. W 1968 r. ukazał się Katalog starych druków Biblioteki Teologicznej Bobo-

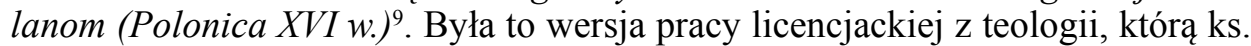
L. Grzebień napisał pod kierunkiem wspomnianego ks. prof. M. Żurowskiego SI. Publikacja była pokłosiem porządkowania księgozbioru „Bobolanum” przeniesionego z Lublina do Warszawy ${ }^{10}$. Prace inwentaryzacyjne prowadzone były pod kierunkiem prof. Alodii Kaweckiej-Gryczowej ${ }^{11}$ i dr Marii Lewańskiej ${ }^{12}$ z Biblioteki Narodowej. W księgozbiorze stwierdzono druki nieznane Estreicherom, w tym dzieła dedykowane dla Jana Łaskiego, arcybiskupa gnieźnieńskiego, czy też kardynała Stanisława Hozjusza. W Książnicy „Bobolanum” zarejestrowano łącznie 125 pozycji Poloników z XVI w. Ks. L. Grzebień zaopatrzył ich spis w indeksy drukarzy oraz proweniencji i wykaz konkordancji13.

Drugą pracą ks. L. Grzebienia wydaną na łamach ABMK był katalog Uzupetnienia do Bibliografii Estreicherów z Biblioteki Teologicznej Bobolanum w Warszawie $^{14}$, liczący łącznie 100 pozycji bibliograficznych. Ks. L. Grzebień swojej kwerendzie poddał nieznane i niedokładnie opisane starodruki od XVI do XVIII wieku, które w większości pochodziły z biblioteki kolegium jezuickiego w Krasnymstawie. Znaczna część zasobu była z daru Michała Potockiego, który w latach 1735-1737 ofiarował publikacje wydane głównie w Królewcu i Gdańsku.

${ }^{8}$ Grzebień, Mistrz nad mistrzami - ksiadz profesor Stanistaw Librowski, s. 70.

${ }^{9} \mathrm{~W} 1968$ r. ks. L. Grzebień obronił licencjat kościelny na podstawie pracy: Nieznane Estreicherom polonica w Bibliotece Teologicznej „Bobolanum”. Na łamach ABMK tekst ukazał się jako: Katalog starych druków Biblioteki Teologicznej Bobolanom (Polonica XVI w.), ABMK, 16 (1968) s. $243-278$.

${ }^{10}$ Biblioteka Bobolanum został założona w 1926 r. jako księgozbiór jezuickiego Wydziału Teologicznego w Lublinie. Po II wojnie światowej przeniesiona wraz z Wydziałem do Warszawy. Zob. L. Grzebień, Wydziat Teologiczny „Bobolanum”, w: Encyklopedia wiedzy o jezuitach na ziemiach Polski i Litwy 1564-1995, red. L. Grzebień, Kraków 1996, s. 771.

${ }^{11}$ Alodia Kawecka-Gryczowa (1903-1990) - historyk kultury, bibliolog i bibliograf, profesor Biblioteki Narodowej oraz Instytutu Badań Literackich PAN. Studiowała polonistykę na Uniwersytecie Warszawskim oraz historię kultury Uniwersytecie Jagiellońskim w Krakowie. W 1932 roku obroniła rozprawę doktorską, a w 1954 została profesorem nadzwyczajnym. Pracowała w Bibliotece Kórnickiej (1928-1930), w Dziale Strych Druków Biblioteki Narodowej (1930-1944, 1950-1974), w Ministerstwie Oświaty (1945-1949) oraz w Instytucie Badań Literackich Polskiej Akademii Nauk (1948-1968), w Pracowni Bibliografii Staropolskiej. Była żoną Józefa Grycza, bibliotekarza i bibliofila, dyrektora Biblioteki Narodowej. Jej zainteresowania badawcze skupiały się na historii drukarstwa i bibliotek, głównie doby renesansu i reformacji. Zasłużyła się w dziele ratowania polskiej książki w czasie II wojny światowej i przyczyniła do ochrony dziedzictwa kultury narodowej. Autorka ponad 100 publikacji naukowych. K. Korotajowa, Alodia Kawecka-Gryczowa 11 VIII 1903 - 16 VI 1990, „Biuletyn Polonistyczny”, 4/3-4 (122-123) 1991 s. 184-191; P. Buchwald-Pelcowa, Wkład Profesor Alodii Kaweckiej-Gryczowej w rozwój nauki o książce, „Z badań nad książka i księgozbiorami historycznymi", 5 (2011) s. 15-26.

${ }^{12}$ Maria Lewańska (Bohonos-Lewańska) - dr, bibliolog, pracowała w Zakładzie Starych Druków Biblioteki Narodowej w Warszawie, której kierownikiem była prof. A. Kawecka-Gryczowa.

${ }^{13}$ L. Grzebień, Katalog starych druków Biblioteki Teologicznej Bobolanom (Polonica XVI w.), ABMK, 16 (1968) s. 243-244.

${ }^{14}$ L. Grzebień, Uzupetnienia do Bibliografii Estreicherów z Biblioteki Teologicznej Bobolanum $w$ Warszawie, ABMK, 19 (1969) s. 45-80. 
Ponad 30 tych pozycji posiadało nie tylko oryginalne oprawy z czerwonej skóry, ale i wytłaczane superekslibrisy donatora ${ }^{15}$. Należy podkreślić, że ks. L. Grzebieniowi udało się zidentyfikować i potwierdzić pozycje książkowe, które nie posiadały not autorskich ani proweniencyjnych. Wspomniany katalog może być traktowany jako wzorcowy m.in. ze względu na sprawdzenie jego poprawności merytorycznej przez dr M. Lewańską z Biblioteki Narodowej ${ }^{16}$.

Wydaje się, że pozytywna ocena prac naukowych ks. L. Grzebienia przez ks. prof. S. Librowskiego, skutkująca ich drukiem na łamach ABMK, była argumentem dla władz zakonnych i samego ks. L. Grzebienia do podjęcia studiów historycznych w KUL. W 1968 r. został on skierowany przez prowincjała jezuitów ks. Stanisława Nawrockiego na studia w Instytucie Historii Kościoła Wydziału Teologicznego KUL. Edukację uniwersytecką ks. L. Grzebień rozpoczął w roku akademickim 1968/1969 ${ }^{17}$. Został przyjęty na seminarium z nauk pomocniczych historii prowadzonym przez ks. prof. S. Librowskiego, wybitnego historyka Kościoła w Polsce i archiwisty ${ }^{18}$. Zaliczenie go do grona seminarzystów było dużym wyróżnieniem, gdyż ks. S. Librowski przyjmował na swoje zajęcia studentów mogących poszczycić się już osiągnięciami naukowymi i rokujących na dalszy rozwój. Stąd też i grono jego seminarzystów było nieliczne, co sprzyjało jednak pracy naukowej ${ }^{19}$. Należy zauważyć, że większość uczniów ks. S. Librowskiego stało się znaczącymi historykami Kościoła w Polsce ${ }^{20}$. Dodatkowym przywilejem uczestniczenia w seminarium była możliwość publikowania najlepszych swoich prac naukowych w półroczniku „Archiwa, Biblioteki i Muzea Kościelnego”, którego redaktorem był ks. S. Librowski ${ }^{21}$.

${ }^{15}$ Tamże.

${ }^{16}$ Autor dziękował za „cenne rady i przeprowadzenie kontroli (...) pracy”. Grzebień, Uzupetnienia do Bibliografii Estreicherów z Biblioteki Teologicznej Bobolanum w Warszawie, s. 46.

${ }^{17}$ Cieślak, Jubileusz o. Ludwika Grzebienia SJ, s. 124.

${ }^{18}$ Nauki pomocnicze historii ks. S. Librowski wykładał w cyklu dwuletnim. W pierwszym roku były to nauka o archiwach, bibliotekarstwie, muzealnictwie i źródłoznawstwie. W drugim natomiast: paleografia, dyplomatyka, sfragistyka, chronologia, genealogia, heraldyka, numizmatyka, metrologia i statystyka. Seminarium z nauk pomocnych obejmowało dwie godziny w tygodniu. Zob. S. Librowski, Kalendarium życia, cierpień, działalności, twórczości i uznania księdza Stanisława Librowskiego. Dokończenie, ABMK, 59 (1990) s. 430, 438-439; A. Weiss, Ksiadz profesor Stanistaw Librowski jako nauczyciel akademicki, w: Ksiadz Stanisław Librowski archiwista, historyk Kościoła i dydaktyk, red. W. Żurek, D. Kiper, Lublin 2015, s. 106-107.

${ }^{19}$ W roku akademickim 1968/1969 na seminarium uczęszczali: doktorant ks. mgr lic. Feliks Lenort oraz magistranci ks. Tadeusz Krahel, ks. Ludwik Grzebień i o. Henryk (Janusz) Zbudniewek paulin. Tak mała liczba seminarzystów wynikała m.in. z wysokich wymagań naukowych stawianym studentom. Zob. Librowski, Kalendarium życia, s. 431; Weiss, Ksiądz profesor Stanisław Librowski jako nauczyciel akademicki, s. 107.

${ }^{20}$ Wśród nich byli m.in. ks. Feliks Lenort, dyrektor Biblioteki WT UAM; ks. Kazimierz Rulka, dyrektor Biblioteki WSD Włocławskiej, o. Janusz Zbudniewek, paulin, profesor ATK i UKSW w Warszawie, ks. Roman Nir, dyrektor Archiwum Polonii w Orchard Lake w USA; ks. bp Jan Kopiec, ordynariusz diecezji gliwickiej i profesor WT Uniwersytetu Opolskiego.

${ }^{21} \mathrm{~W}$ ABMK opublikowano w postaci artykułów prace dyplomowe, np. H.J. Zbudniewek, Kopiarz dokumentów konwentu Paulinów w Wieruszowie (I), ABMK, 26 (1973) s. 199-261; 
Ks. L. Grzebień w swoich badaniach naukowych kontynuował problematykę historycznych księgozbiorów. Zapoznając się z dotychczasowym piśmiennictwem dotyczącym prywatnych i kościelnych zbiorów w epoce renesansu, szczególną uwagę zwrócił na publikacje ówczesnego dyrektora Archiwum Uniwersytetu Jagiellońskiego dr. Leszka Hajdukiewicza. Osobiście konsultował z nim również niektóre zagadnienia związane z przygotowywaną pracą magisterską. Na podstawie poznanej literatury dotyczącej polskich bibliotek prywatnych $\mathrm{w}$ okresie renesansu ks. L. Grzebień opublikował na łamach ABMK recenzję czterech publikacji, odnoszących się do tego zagadnienia (Duchowieństwo polskiego odrodzenia a ksiązka. Na marginesie czterech ksiażek o bibliotekach personalnych) ${ }^{22}$. Szczególną wartością opisywanych książek według opinii ks. L. Grzebienia, był zamieszczony dodatek źródłowy w postaci inwentarzy księgozbiorów. W swojej konkluzji wyraził on wdzięczność autorom za przybliżenie księgozbiorów XVI-wiecznych duchownych bibliofili, którzy swoją pasją świadczyli o zaangażowaniu się ludzi Kościoła w problemy kultury ${ }^{23}$.

Wspomniane wyżej publikacje ks. L. Grzebień wykorzystał podczas pisania pracy magisterskiej o księgozbiorze XVI-wiecznego biskupa włocławskiego Hieronima Rozrażewskiego. Temat zaproponował mu ks. S. Librowski jako kontynuację swoich badań nad tym hierarchą kościoła włocławskiego, które sam zwieńczył dysertacją doktorską ${ }^{24}$. Już po niecałych dwóch latach studiów historycznych (1970) ks. L. Grzebień przedstawił pracę magisterską pt. Biblioteka biskupa Hieronima Rozrażewskiego (1542-1600). Ks. S. Librowski ocenił ją na bardzo dobrą notę. Recenzentem pracy, uznanej również jako licencjat kościelny, był ks. prof.

Część 2: Treść dokumentów kopiarza, ABMK, 27 (1973) s. 207-260; T. Krahel, Schematyzmy Diecezji Wileńskiej jako źródto historyczne (I), ABMK, 38 (1979) s. 109-149; Schematyzmy Diecezji Wileńskiej jako źródto historyczne (II), ABMK, 39 (1979) s. 191-235; K. Rulka, Stan badań nad księgozbiorami Diecezji Włocławskiej oraz postulaty badawcze na przyszłość, ABMK, 26 (1973) s. 5-57; Z. Różański, Księgi liturgiczne Biblioteki Seminarium Duchownego we Włocławku. Studium liturgiczno-źródtoznawcze, ABMK, 42 (1981) s. 59-149; S. Librowski, Dwadzieścia pięć tomów czasopisma „Archiwa, Biblioteki i Muzea Kościelne”, ABMK, 25 (1972) s. 16.

${ }^{22}$ Ocena ks. S. Grzebienia dotyczyła następujących książek: W. Szelińska, Biblioteki profesorów Uniwersytetu Krakowskiego w XV i poczatkach XVI wieku, Wrocław 1966; A. Lewicka-Kamińska, Renesansowy księgozbiór Mikołaja Czepla w Bibliotece Jagiellońskiej, Wrocław 1956; L. Hajdukiewicz, Biblioteka Macieja z Miechowa, Wrocław 1960; L. Hajdukiewicz, Księgozbiór $i$ zainteresowania bibliofilskie Piotra Tomickiego na tle jego działalności kulturalnej, Wrocław 1961. Zob. L. Grzebień, Duchowieństwo polskiego odrodzenia a ksiązka. Na marginesie czterech ksiażek o bibliotekach personalnych, ABMK, 21 (1970) s. 295-300.

${ }^{23}$ Tamże, s. 302.

${ }^{24}$ Pracę doktorską pt. Hieronim Rozrażewski, biskup kujawski i pomorski ks. S. Librowski obronił na Uniwersytecie Warszawskim w $1951 \mathrm{r}$. 
Bolesław Kumor ${ }^{25}$. Dysertacja została wydrukowana w tomie 22 (1971) ABMK ${ }^{26}$. Jak napisał autor:

Celem (...) pracy jest ukazanie poprzez bogaty renesansowy księgozbiór biskupa Hieronima Rozrażewskiego nie tylko oblicza humanisty i bibliofila, ale też działacza i pasterza diecezji ${ }^{27}$.

Ks. L. Grzebień w swojej dysertacji oparł się na bogatych źródłach archiwalnych, z których najważniejszym był testament biskupa z 1599 r. oraz wykaz książek biblioteki spisany po śmierci hierarchy w 1600 r., znajdujący się w księdze testamentów krakowskiej kapituły. Bogata spuścizna wymagała jednak żmudnej pracy badawczej. Wspomniany spis posiadał tylko skrócone tytuły, najczęściej bez podania autora dzieła. Najwięcej trudu ks. L. Grzebień musiał poświecić na poprawne odczytanie tytułów książek, a następnie na ustalenie ich autorstwa oraz proweniencji. Podczas kwerendy ujawniła się duża cierpliwość i benedyktyńska wręcz praca ks. L. Grzebienia. Podczas swoich badań starał się dotrzeć do jak największej liczby egzemplarzy, aby in extenso opisać każdą książkę. Niezwykle cennym dodatkiem pracy jest spis biblioteki bpa H. Rozrażewskiego, który powstał na podstawie testamentu i inwentarza z $1600 \mathrm{r}$. Wspomniana publikacja ks. L. Grzebienia świadczy o jego dużych kompetencjach badawczych, choć był poczatkującym adeptem historii ${ }^{28}$.

Po uzyskaniu magisterium w 1970 r. ks. L. Grzebień powrócił do Krakowa. Do Lublina przyjeżdżał tylko na seminarium doktoranckie prowadzone przez ks. S. Librowskiego. Pobyt w krakowskim klasztorze jezuitów związany był z możliwością prowadzenia przez niego kwerend w archiwum zakonnym do przygotowywanej pracy doktorskiej poświęconej bibliotekom jezuickim w okresie staropolskim. W celu poszerzenia bazy źródłowej ks. L. Grzebień przeprowadził również konieczne badania w centralnym archiwum jezuitów w Rzymie ${ }^{29}$.

Niezwykła pracowitość i zdolności intelektualne ks. L. Grzebienia zaowocowały szybkim napisaniem przez niego pracy doktorskiej. Już po roku od uzyskania magisterium (1971) złożył on dysertację pt. Organizacja bibliotek jezuickich w Polsce od XVI do XVIII wieku ${ }^{30}$. Jak wspominał, ks. S. Librowski ,życzliwie” ją przyjął, ale wysunął zarzut, że zbyt szybko powstała i należy jeszcze poczekać z jej obroną ${ }^{31}$. Ostatecznie ks. S. Librowski sporządził opinię promotorską w dniu

${ }^{25}$ W swoim Kalendarium życia ks. S. Librowski zapisał: „We wtorek 14 kwietnia 1970 r. wspomniany przekazał do Dziekanatu własną recenzję pracy magisterskiej i licencjackiej swojego seminarzysty ks. Ludwika Grzebienia, jezuity pt. Biblioteka biskupa Hieronima Rozrażewskiego (1542-1600). Ocenił ją na bardzo dobrze oraz w sobotę 13 czerwca uczestniczył w jego egzaminie magisterskim i w obronie rozprawy. Drugim recenzentem był ks. prof. Bolesław Kumor. S. Librowski. Kalendarium życia, s. 439.

${ }^{26}$ L. Grzebień, Biblioteka biskupa Hieronima Rozrażewskiego (1542-1600), ABMK, 22 (1971) s. $61-168$.

${ }^{27}$ Tamże, s. 61.

${ }^{28}$ Tamże, s. 62.

${ }^{29}$ Cieślak, Jubileusz o. Ludwika Grzebienia SJ, s. 125.

${ }^{30}$ Jak zaznaczył ks. L. Grzebień, pracę przygotowywał w latach 1969-1971.

${ }^{31}$ Grzebień, Mistrz nad mistrze - ksiądz profesor Stanisław Librowski, s. 72. 
20 czerwca 1971 r., wystawiając dysertacji notę bardzo dobrą. Recenzentami doktoratu byli ks. prof. Bolesław Kumor i doc. dr hab. Leszek Hajdukiewicz z Uniwersytetu Jagiellońskiego ${ }^{32}$. W dniu 3 grudnia 1971 r. odbył się egzamin i publiczna obrona pracy doktorskiej podczas posiedzenia Rady Wydziału Teologicznego. Ks. L. Grzebień był uroczyście promowany na doktora 5 czerwca $1972 \mathrm{r}^{33}$

Dysertacja doktorska ukazała się na łamach ABMK w dwóch częściach ${ }^{34}$. Jak napisał autor:

Praca ta nie ma na celu szczegółowego ukazania przeszłości każdej jezuickiej biblioteki, bo to wymagałoby długich i żmudnych poszukiwań archiwalnych, może jednak dopomóc adeptom badań przeszłości księgozbiorów jezuickich do zrozumienia organizacji życia zakonnego, powiązania bibliotek na terenie tej samej placówki oraz ich zależność od poszczególnych przełożonych. Ukaże możliwie obiektywnie obraz polityki bibliotecznej, sprowadzania, porządkowania, czy korzystania ze zbiorów zgromadzonych przez daną placówkę ${ }^{35}$.

Swoją pracę doktorską ks. L. Grzebień podzielił na cztery tematyczne części. Pierwsza dotyczyła organizacji bibliotek w zakonie jezuitów, ze szczególnym podziałem na księgozbiory w domach zakonnych i formacyjnych. W drugiej części przedstawił gromadzenie zbiorów bibliotecznych poprzez ukazanie procesu ich zakładania i powiększania. Przeprowadził również analizę zawartości treściowej biblioteki jezuickiej. Kolejna część poświęcona została problemowi przechowywania i porządkowania zbiorów, w której ukazano nie tylko pomieszczenia biblioteczne czy też układ książek w księgozbiorze, ale również pomoce biblioteczne (katalogi) oraz prace introligatorskie, zachowane ekslibrisy i napisy proweniencyjne. W ostatniej części omówił udostępnianie zasobu bibliotecznego klasztorów jezuickich, nie tylko zakonnikom, ale i świeckim, wymianę międzybiblioteczną oraz zagadnienie posiadania $\mathrm{w}$ jezuickich księgozbiorach książek zakazanych przez władze kościelne.

Chronologicznie praca obejmuje czas od 1564 r., czyli przybycia jezuitów do Lidzbarka Warmińskiego na zaproszenie kardynała Stanisława Hozjusza, do 1773 r., kiedy zakon został rozwiązany przez papieża Klemensa XIV. Dysertacja dotyczy wszystkich czterech prowincji jezuickich w Rzeczpospolitej, ale również klasztorów poza jej granicami, które w pewnym okresie były przynależne do polskiej wspólnoty zakonnej. Ks. L. Grzebień oparł się szerokiej podstawie źródłowej. Podstawowe były katalogi biblioteczne, które są przechowywane w wielu bibliotekach polskich i zagranicznych. Dodatkowo autor wykorzystał również archiwalia jezuickie nie tylko polskiej proweniencji, ale również ze zbiorów zagranicznych: z Rzymu, Sztokholmu, Uppsali czy Wiednia. W publikacji na uwagę zasługuje również dodatek źródłowy zawierający najważniejsze regulaminy

${ }^{32}$ Librowski, Kalendarium życia, s. 458.

${ }^{33}$ Tamże.

${ }^{34}$ L. Grzebień, Organizacja bibliotek jezuickich w Polsce od XVI do XVIII wieku (I), ABMK, 30 (1975) s. 223-278; Organizacja bibliotek jezuickich w Polsce od XVI do XVIII wieku (II) ABMK, 31 (1975) s. 225-281. Dysertacja, po uaktualnieniu, ukazała się drukiem również w 2013 r. Zob. L. Grzebień, Organizacja bibliotek jezuickich w Polsce od XVI do XVIII wieku, Kraków 2013.

${ }^{35}$ Grzebień, Organizacja bibliotek jezuickich w Polsce od XVI do XVIII wieku (I), s. 223. 
bibliotek jezuickich obowiązujące w ich domach zakonnych w Rzeczpospolitej. Praca do dziś jest uznawana za wybitną i pomimo upływu kilkudziesięciu lat od jej wydania na łamach ABMK, nadal nie straciła na swojej wartości. Z tego też względu ks. L. Grzebień zdecydował się wydać ją ponownie w 2013 r. jako publikację samoistną, rozszerzając i uaktualniając jej bibliografię, szczególnie o najnowsze pozycje ${ }^{36}$.

Już w dwa tygodnie po uroczystej promocji doktorskiej, ks. S. Librowski zaproponował ks. L. Grzebieniowi stanowisko asystenta naukowego w Katedrze Nauk Pomocniczych Historii i Metodologii Historii, której był kierownikiem. Propozycję ks. L. Grzebień przyjął, choć po latach zapisał, że „Kończąc studia na KUL-u, miałem własne plany pracy naukowej w Krakowie, które nie pokrywały się z planami mojego mistrza księdza Librowskiego" ${ }^{37}$. Wniosek o zatrudnienie uzyskał w dniu 24 czerwca 1972 r. poparcie dziekana Wydziału Teologii ks. prof. Władysława Poplatka, a także pozytywną opinię Rady Wydziału Teologii ${ }^{38}$. Po wyrażeniu zgody Prorektora KUL prof. Stefana Sawickiego, ks. L. Grzebień od 1 października 1972 r. rozpoczął pracę jako asystent-stażysta z miesięczną pensją $2000 \mathrm{zt}^{39}$. Zakres jego obowiązków miał określić kierownik katedry ks. S. Librowski. Zgodnie z pismem prorektora S. Sawickiego z dnia 27 listopada 1972 r. ks. L. Grzebieniowi zlecono następujące zajęcia w roku akademickim 1972/1973: ćwiczenia z bibliotekoznawstwa (1 godzina w tygodniu), ćwiczenia z nauk pomocniczych historii (1 godzina $\mathrm{w}$ tygodniu), ćwiczenia $\mathrm{z}$ historii Kościoła (2 godziny w tygodniu) - teologiczne studia magisterskie (kurs zwykły) oraz 19 godzin w tygodniu zajęć zakładowych ${ }^{40}$. Ks. S. Librowski zanotował bardziej szczegółowo prowadzone zajęcia przez ks. L. Grzebienia, z rozpisaniem ich na

${ }^{36}$ B. Kubiak, Ludwik Grzebień SJ, Organizacja bibliotek jezuickich w Polsce od XVI do XVIII wieku, Kraków 2013, 250 stron, „Studia Podlaskie”, 21 (2013) s. 397-399.

${ }^{37}$ Grzebien, Mistrz nad mistrze - ksiadz profesor Stanisław Librowski, s. 73. Taką opinię sformułował już w liście z dnia 13 VI 1970 r. do prowincjała o. S. Nawrockiego SI, po uzyskaniu magisterium. Zob. S. Cieślak, Jubileusz o. Ludwika Grzebienia SJ, s. 125.

${ }^{38}$ Archiwum Uniwersyteckie KUL (dalej: AUKUL), sygn. A-1148, Referat Personalny, Akta osobowe pracowników, Grzebień Ludwik ks. (1972-1974), Pismo do Rektoratu 27 VI 1972 dziekana Wydziału Teologii KUL, ks. prof. W. Poplatka. Jak zapisał w Kalendarium życia ks. S. Librowski: „Na propozycję ks. prof. Librowskiego z poniedziałku 19 czerwca 1972 r., Rada Wydziału Teologicznego, na swym posiedzeniu w dniu sobotę 24 czerwca, zaangażowała z dniem 1 października tr. na asystenta przy katedrze nauk pomocniczych i metodologii historii ks. dra Ludwika Grzebienia, jezuitę". Librowski, Kalendarium życia, s. 457.

${ }^{39}$ Oficjalne pismo od prorektora S. Sawickiego informujące o zatrudnieniu ks. L. Grzebień otrzymał dopiero 12 października 1972 r. Wysokość wynagrodzenia była zgodna z rozporządzeniem Rady Ministrówa) z dnia 27 kwietnia 1972 r. AUKUL, sygn. A-1148, Pismo Prorektora KUL prof. S. Sawickiego do ks. L. Grzebienia z dnia 12 X 1972 r.

${ }^{40}$ AUKUL, sygn. A-1148, Pismo Prorektora KUL prof. S. Sawickiego z dnia 27 XI 1972 r. W piśmie ks. L. Grzebienia z 2 II 1973 r. informował on następujących zajęciach „dydaktyczno-wychowawczych": ćwiczenia z bibliotekoznawstwa dla I roku historii Kościoła (doktoranckie) 1 godzina w tygodniu; ćwiczenia z nauk pomocniczych historii Kościoła okresu nowożytnego dla II roku (doktoranckie) - 1 godzina w tygodniu oraz ćwiczenia z historii Kościoła dla I roku teologii kurs B, 2 godziny w tygodniu. AUKUL, sygn. A-1148, Wniosek awansowy ks. L. Grzebienia. 
poszczególne lata studiów. Dla studentów I i II roku studiów doktoranckich miał on ćwiczenia z nauk pomocniczych historii XIX i XX wieku dla II roku (1 godzina w tygodniu) oraz ćwiczenia $\mathrm{z}$ bibliotekoznawstwa (1 godzina w tygodniu). $\mathrm{Na}$ teologicznych studiach magisterskich (kurs B $)^{41}$ prowadził ćwiczenia z metodologii historii na I roku (2 godziny w tygodniu $)^{42}$. Ponadto brał udział w seminarium naukowym prowadzonym przez ks. S. Librowskiego (2 godziny w tygodniu) oraz pełnił dyżur w Zakładzie Historii Kościoła (część etatu) ${ }^{43}$. Jak zauważamy, ćwiczenia z historii Kościoła dla studentów kursu B dotyczyły metodologii historii. W piśmie prorektora nie wpisano udziału ks. S. Grzebienia w seminarium naukowym ks. S. Librowskiego, ale wynikało z pewnej praktyki uczelnianej, że asystent uczestniczy w zajęciach swojego mistrza.

Po zatrudnieniu w Instytucie Historii Kościoła ks. L. Grzebień prowadził ożywioną działalność badawczo-wydawniczą. W 1972 r. opublikował łącznie pięć tekstów naukowych. Na łamach ABMK wydrukował dwa artykuły. Pierwszy z nich to Centralny Katalog Inkunabułów Bibliotek polskich (powstanie katalogu, osiagnięte wyniki i płynące stad wnioski). Jego ocena dotyczyła monumentalnego dzieła Incunabula quae in bibliothecis Poloniae esservantur/ Inkunabuly $w$ bibliotekach polskich. Centralny katalog autorstwa Alodii Kaweckiej-Gryczowej z udziałem Marii Bohonos i Elizy Szandorowskiej, który powstał w Bibliotece Narodowej ${ }^{44}$. Jak wspomniano wyżej, ks. L. Grzebień pracował pod kierunkiem prof. A. Kaweckiej-Gryczowej przy porządkowaniu starodruków biblioteki „Bobolanum” i uważał się za jej ucznia. Nabyta wówczas wiedza i umiejętności pomogły modemu badaczowi w dalszej pracy nad jezuickimi bibliotekami w Polsce. $Z$ uznaniem wypowiadał się o jej osiągnięciach, uważając ją za najwybitniejszą znawczynię inkunabułów w Polsce. Wspomniany katalog stawiał jako wzorzec dla dalszych badań bibliotecznych. Ze szczególnym uznaniem podkreślił skatalogowanie zbiorów inkunabułów wszystkich kościelnych bibliotek diecezjalnych, seminaryjnych, kapitulnych i największych zakonnych. Ks. L. Grzebień postulował, aby wzorem tego katalogu opracowano wykaz alfabetyczny proweniencji inkunabułów oraz ich opraw. Zaproponował również powstanie

\footnotetext{
${ }^{41}$ Był to tzw. kurs niższy czyli teologiczne studia magisterskie dla studentów świeckich i sióstr zakonnych.

${ }^{42} \mathrm{~W}$ piśmie prorektora zapisano, że są to ćwiczenia z Historii Kościoła. AUKUL, sygn. A-1148, Pismo Prorektora KUL prof. S. Sawickiego z dnia 27 XI 1972 r.

${ }^{43}$ Librowski, Kalendarium życia, s. 466.

${ }^{44}$ A. Kawecka-Gryczowa, M. Bohonos, E. Szandrowska, Incunabula quae in bibliothecis Poloniae esservantur/ Inkunabuly w bibliotekach polskich. Centralny katalog, t. 1-2, Wrocław 1970. Uzupełniniem katalogu jest wydany w 1994 tom zawierający dodatki, thumaczenia i corrigentę. Zob. M. Bohonos, E. Szandorowska, M. Spandowski, A. Kawecka-Gryczowa, Incunabula quae in bibliothecis Poloniae asservantur. 2, Addenda, indices, Wrocław 1994.
} 
centralnego katalogu poloników XVI wieku ${ }^{45}$ oraz katalogu dodatków do narodowej bibliografii Estreicherów. Jak możemy zauważyć, niektóre postulaty zostały $\mathrm{z}$ czasem zrealizowane ${ }^{46}$.

Jedynym artykułem autorstwa ks. L. Grzebienia na łamach ABMK niezwiązanym $\mathrm{z}$ księgozbiorami był okolicznościowy tekst poświęcony jubileuszowi wydawnictwa jezuitów w Krakowie, które w 1972 r. obchodziło stulecie swojej działalności. Autor opisał dzieje Wydawnictwa Apostolstwa Modlitwy powstałego w 1872 r., które zasłynęło wydawaniem „Posłańca Serca Jezusowego” pod redakcją ks. Stanisława Stojałowskiego ${ }^{47}$. Wspomniany tekst był niejako streszczeniem monografii o dziejach tej oficyny, którą opublikował w tym samym roku razem z Zofią Wilkosz ${ }^{48}$. W publikacji tej zamieścił zarówno słowniczek wybranych pisarzy jezuickich ${ }^{49}$, jak i bibliografię retrospektywną wydawnictw WAM $^{50}$. Poznanie przez niego specyfiki wydawnictwa, jego struktury i założeń ideowych oraz wyzwań stojących przed oficyną w zmieniających się warunkach społeczno-politycznych Polski czasu buntu Solidarności, zdecydowało o powierzeniu mu przez władze zakonne funkcji dyrektora wydawnictwa, którą pełnił w latach $1981-1985^{51}$.

W czasie pracy w KUL ks. L. Grzebień nawiązał również długoletnią współpracę z redakcją „Polskiego Słownika Biograficznego” stając się z czasem jed-

${ }^{45}$ Rejestrację poloników prowadzi Biblioteka Narodowa. Aktualnie publikowana jest seria wydawnicza Polonika XVI-XVIII wieku w bibliotekach rzymskich. Dotychczas ukazały się: M. Spandowski, Katalog starych druków biblioteki Papieskiego Kolegium Polskiego w Rzymie, Warszawa 2010; M. Spandowski, P. Pludra-Żuk, Katalog poloników biblioteki Pontificia Università Urbaniana, Warszawa 2012; K. Soliński, Katalog poloników w Biblioteca Universitaria Alessandrina, Warszawa 2014; K. Soliński, Katalog starodruków biblioteki Papieskiego Instytutu Studiów Kościelnych w Rzymie, Warszawa 2016; K. Soliński, Katalog poloników w Biblioteca Casanatense, Warszawa 2016; K. Soliński, Katalog poloników w Biblioteca dell'Accademia Nazionale dei Linceie Corsiniana, Warszawa 2019.

${ }^{46} \mathrm{~W}$ Krakowie funkcjonuje Centrum Badawcze Bibliografii Polskiej Estreicherów przy Uniwersytecie Jagiellońskim, które kontynuuje prace bibliograficzne Estreichera. Udostępnia ona Elektroniczną Bazę Bibliografii Estreichera (EBBE). Strona: https://www.estreicher.uj.edu.pl/home/ (dostęp: 02.01.2020).

${ }^{47}$ L. Grzebień, Stulecie wydawnictwa jezuickiego w Krakowie, ABMK, 25 (1972) s. 229-237.

${ }^{48}$ L. Grzebień, Z. Wilkosz, Wydawnictwo Apostolstwo Modlitwy 1872-1972. Historia, opracowania, bibliografia, Kraków 1972. Uaktualniona wersja ukazała się w 1997. Zob. Wydawnictwo WAM 1972-1997. Historia, bibliografia, Kraków 1997.

${ }^{49}$ L. Grzebień, Stowniczek ważniejszych pisarzy jezuitów, w: Wydawnictwo Apostolstwo Modlitwy 1872-1972. Historia, opracowania, bibliografia, Kraków 1972, s. 199-216.

${ }^{50}$ Bibliografia retrospektywna wydawnictw wlasnych i przejętych /WAM/, oprac. L. Grzebień, Z. Wilkosz, Kraków 1972, s. 217-476.

${ }^{51} \mathrm{~W}$ tym czasie udało się mu nie tylko utrzymać działalność wydawnictwa, uzyskując u władz państwowych zgodę na druk książek i czasopism (m.in. reaktywował „Posłańca Serca Jezusowego"), ale również zabiegał skutecznie o koncesję na własną drukarnię. Samo wydawnictwo przekształcił w nowoczesną oficynę wydającą publikacje o łącznym nakładzie 500000 egzemplarzy. Z jego inicjatywy doszło do budowy tzw. Domu Pisarzy, gdzie umieszczono biuro i drukarnie Wydawnictwa Apostolstwa Modlitwy i Bibliotekę Naukową. Cieślak, Jubileusz o. Ludwika Grzebienia SJ, s. 126-127; Terlecki, Pasja historyka. Ojca Ludwika Grzebienia życie i praca, s. 20. 
nym z najpłodniejszych autorów tego wydawnictwa. W 1972 r. opublikował swoje pierwsze hasło „Lisikiewicz Józef” ${ }^{52}$.

W lutym 1973 r. ks. L. Grzebień złożył wniosek o awans na stanowisko starszego asystenta. Ks. S. Librowski tak ocenił w dniu 15 lutego 1973 r. pracę swojego asystenta po kilku miesiącach pracy w KUL:

1. Praca naukowa, wyrażająca się na pierwszym miejscu w publikacjach, zasługuje na podkreślenie.

2. Zajęcia dydaktyczne ks. dr Grzebień spełnia bez zarzutu.

3. Postawa moralna omawianego pracownika bardzo dobra.

4. Biorąc wszystko pod uwagę stawiam wniosek, ażeby ks. Ludwika Grzebienia, który już drugi rok po doktoracie, pracuje naukowo i publikuje, awansować na starszego asystenta przy katedrze nauk pomocniczych historiii ${ }^{53}$.

Wniosek ks. S. Librowskiego poparł dziekan Wydziału Teologii ks. prof. Marian Rechowicz. Dotychczasowa praca ks. L. Grzebienie spotkała się z uznaniem także ze strony Rady Wydziału, która na swoim posiedzeniu w dniu 22 lutego 1973 r. poparła przedłużenie jego zatrudnienia w roku akademickim 1973/1974 oraz awansowanie na stanowisko starszego asystenta ${ }^{54}$. Również Rektorska Komisja ds. Kadry Naukowo-Dydaktycznej w dniu 23 marca 1973 r. przychyliła się jednogłośnie do wniosku awansowego ks. L. Grzebienia, jednak postawiła warunek zdania przez niego języka obcego do końca kwietnia 1973 r. Ostatecznie Rektor KUL o. prof. Mieczysław Albert Krąpiec zdecydował o awansie na starszego asystenta pod wspomnianym wyżej warunkiem ${ }^{55}$.

Ks. L. Grzebień chcąc podnieść swoje umiejętności językowe, jeszcze przed decyzją Rektora, w dniu 14 marca 1973 r. wystosował do niego pismo z prośbą o udzielenie płatnego urlopu w terminie od 1 lipca do 30 września 1973 r. w celu odbycia kursu języka angielskiego w School of English Studies w Folkestone (Kent). Kurs ten załatwił i opłacił we własnym zakresie ${ }^{56}$. Przedstawiony wniosek uzyskał zgodę rektora KUL ${ }^{57}$.

W międzyczasie ks. L. Grzebień zmienił jednak swoje plany, ponieważ postanowił połączyć podczas swojego pobytu w Wielkiej Brytanii sprawy naukowe (kurs językowy, kwerendy archiwalne) z powinnościami wynikającymi z przynależności do zakonu jezuitów, tj. odbycie końcowej fazy formacji zakonnej. Z tego też względu wystąpił on do Rektora KUL w dniu 18 czerwca 1973 r. z prośbą o zgodę na udzielenie mu tym razem rocznego urlopu bezpłatnego od sierpnia

${ }^{52}$ L. Grzebień, Lisikiewicz Józef, w: Polski Stownik Biograficzny, t. 17, red. E. Rostworowski, Wrocław 1972, s. 461-462.

${ }^{53}$ AUKUL, sygn. A-1148, Wniosek o awans ks. L. Grzebienia 1973 r.

${ }^{54}$ Głosowało 19 członków Rady Wydziału Teologii, z których 16 poparło wniosek, a 3 wstrzymało się od głosu. AUKUL, sygn. A-1148, Wniosek o awans ks. L. Grzebienia 1973 r.

${ }^{55}$ Tamże.

${ }^{56}$ AUKUL, sygn. A-1148, Pismo ks. dra L. Grzebienia do Rektora KUL o. prof. A. Krąpca $\mathrm{z}$ dnia 14 III $1973 \mathrm{r}$.

${ }^{57}$ Prorektor KUL prof. S. Sawicki udzielił pismem tego samego dnia (14 III 1973 r.) ks. L. Grzebieniowi płatnego urlopu (w tym 6 tygodni urlopu wypoczynkowego) we wnioskowanym terminie 1 VII - 30 IX 1973 r. AUKUL, sygn. A-1148, Pismo Prorektora KUL prof. S. Sawickiego do ks. dr L. Grzebienia z dnia 14 III 1973 r., 
1973 r. do sierpnia 1974 r. Jak argumentował w podaniu, w tym terminie miał odbyć końcową fazę jezuickiej formacji zakonnej, tzw. trzecią probację. Prośba, poparta przez prowincjała o. Stanisława Nawrockiego $\mathrm{SI}^{58}$ oraz Radę Wydziału Teologicznego ${ }^{59}$, uzyskała zgodę prorektora S. Sawickiego ${ }^{60}$. Z pisma prowincjała dowiadujemy się, że władze zakonne zgodziły się na zatrudnienie ks. L. Grzebienia w Instytucie Historii Kościoła, jednak pod warunkiem, że po roku pracy w KUL, będzie on mógł udać się na roczną probację ${ }^{61}$.

Zgodnie z udzielonym pozwoleniem władz KUL ks. L. Grzebień przebywał w roku akademickim 1973/1974 na rocznym urlopie naukowym w Wielkiej Brytanii, gdzie uczył się języka angielskiego, prowadził kwerendy archiwalne oraz odbywał formację zakonną ${ }^{62}$.

W rocznej opinii ks. prof. S. Librowskiego z dnia 19 lutego 1974 r. napisał on:

Na rok akademicki 1973/74 ks. dr Grzebień otrzymał urlop od Rady Wydziału. (...) W czasie urlopu m.in. odbywał w Anglii kurs języka angielskiego, potrzebny mu na do awansu na starszego asystenta.

Zajęcia dydaktyczne w roku ak[ademickim] 1972/73 wypełniał umiejętnie i sumiennie. Pracował też naukowo i publikował. Obecnie przystępuje się do druku jego pracy doktorskiej o bibliotekach jezuickich w Polsce na przestrzeni XVI-XVIII wieku ${ }^{63}$.

Uzupełnieniem tej opinii była wpis ks. prof. Bolesława Kumora:

Ks. L. Grzebień, urlopowany w roku akad[emickim] 1973/74, w poprzednim roku akad[emickim] wywiązywał się dobrze ze swoich obowiązków, jest dobrze przygotowany, publikuje w każdy rok nowe artykuły, a nawet książki.

Uważam, że jest dobrym pracownikiem I[nstytutu] H[istorii] K[ościoła ${ }^{64}$.

Na podstawie tych rekomendacji Rada Wydziału Teologicznego w dniu 25 lutego 1974 r. wystąpiła z wnioskiem o przedłużenie angażu ks. L. Grzebienia na stanowisku asystenta w roku akademickim 1974/1975 ${ }^{65}$. Rektor KUL o. M.A. Krąpiec zgodził się na przedłużenie zatrudnienia na stanowisku asystenta ${ }^{66}$.

${ }^{58}$ AUKUL, Pismo Małopolskiego Prowincjała Jezuitów ks. Stanisława Nawrockiego SI do Rady Wydziału Teologicznego KUL na ręce Ks. Dziekana Prof. Dra Edwarda Kopcia z dnia 10 IV $1973 \mathrm{r}$.

${ }^{59}$ AUKUL, sygn. A-1148, Protokół posiedzenia Rady Wydziału Teologicznego z dnia 23 VI $1973 \mathrm{r}$.

${ }^{60}$ AUKUL, sygn. A-1148, Pismo rektora S. Sawickiego z dnia 30 VI 1973. r.

${ }^{61}$ AUKUL, sygn. A-1148, Pismo Małopolskiego Prowincjała Jezuitów ks. Stanisława Nawrockiego SI do Rady Wydziału Teologicznego KUL na ręce Ks. Dziekana Prof. Dra Edwarda Kopcia z dnia 10 IV $1973 \mathrm{r}$.

${ }^{62}$ Jak zapisał ks. S. Librowski: „Ks. dr Ludwik Grzebień, asystent przy katedrze ks. prof. Librowskiego, znajdował się na rocznym urlopie naukowym i przebywał za granicą”. Librowski, $\mathrm{Ka}$ lendarium życia, s. 477.

${ }^{63}$ AUKUL, sygn. A-1148, Kwestionariusz 1974 r.

${ }^{64}$ Tamże.

${ }^{65} \mathrm{~W}$ tajnym głosowaniu brało udział 22 członków Rady Wydziału, z których 21 poparło wniosek, a 1 wstrzymał się od głosu. AUKUL, sygn. A-1148, Kwestionariusz 1974.

${ }^{66}$ AUKUL, sygn. A-1148, Kwestionariusz 1974 r. 
Pomimo tej decyzji ks. L. Grzebień nie powrócił już do pracy w KUL, przedłużając swój pobyt w Wielkiej Brytanii ${ }^{67}$. W dniu 30 października 1974 r. dziekan Wydziału Teologicznego KUL ks. prof. Edward Kopeć poinformował Rektorat KUL, że ks. L. Grzebień „nie podjął zajęć”. Tego samego dnia Referat Personalny KUL wystosował zawiadomienie do ks. L. Grzebienia podpisane przez prorektora prof. S. Sawickiego z informacją, że w dniu 30 września został on skreślony $\mathrm{z}$ ewidencji pracowników $\mathrm{KUL}^{68}$. Ks. S. Librowski w swoim Kalendarium napisał „(...) przyczyną tego było przebywanie za granicą bez pozwolenia kierownika katedry i Dziekanatu" ${ }^{69}$.

Rezygnacja z etatu na KUL przez ks. L. Grzebienia wynikała, jak sam zapisał, $\mathrm{z}$ rozbieżności jego planów pracy naukowej z zadaniami stawianymi przez ks. prof. S. Librowskiego, o których wspomniano wyżej ${ }^{70}$. Dodatkowo wydaje się, że podczas ich rocznej współpracy ujawniły się zbyt duże różnice charakterów, co uniemożliwiało dalszą owocną pracę. Jak wspominał ks. S. Grzebień: „,[ks. S. Librowski] był niełatwy w bliższej współpracy" "71

Pomimo nagłej rezygnacji przez ks. L. Grzebienia z pracy w KUL wydaje się, że ks. S. Librowski nie żywił do niego żalu o tę decyzję. Znamienne jest jednak, że na łamach ABMK nie została już opublikowana żadna praca ks. L. Grzebienia $^{72}$. Pewnym miernikiem dalszych dobrych ich relacji jest fakt, że w dniu 1 marca 1978 r. ks. S. Librowski skierował list do swoich wychowanków ${ }^{73}$, m.in. ks. L. Grzebienia, z prośbą o nadesłanie przez nich życiorysu oraz wykazu drukowanych prac. Jak zapisał ks. S. Librowski, ,jednym z [jego] celów naukowych było pozostawienie po sobie uczniów. Pragnąc pomóc wyróżniającym się spośród nich, postanowił wciągnąc ich do Towarzystwa Naukowego Katolickiego". Po otrzymaniu stosownych dokumentów zarekomendował on ks. L. Grzebienia do przyjęcia w poczet członków Towarzystwa. W dniu 2 maja 1978 r. został on jednomyślnie przyjęty przez Wydział Teologiczno-Kanoniczny Towarzystwa Naukowego do grona członków ${ }^{74}$.

${ }^{67}$ Po zakończeniu probacji w maju 1974 r. ks. L. Grzebień udał się do Rzymu, gdzie prowadził kwerendy naukowe w archiwum generalnym jezuitów, dotyczące misji jezuickich. Badania prowadził również w klasztorach jezuickich w Stanach Zjednoczonych oraz w stacjach misyjnych w Zambii. Owocem pogłębionych badań była książka uznana za habilitację na ATK pt. Pionierski trud misjonarzy stowiańskich 1881-1969. Wśród ludu Zambii, t. 1, Kraków 1977.

${ }^{68}$ AUKUL, sygn. A-1148, Pismo Referatu Personalnego do ks. dra L. Grzebienia z dnia 30 X $1974 \mathrm{r}$

${ }^{69}$ Librowski, Kalendarium życia, s. 488.

${ }^{70}$ Grzebień, Mistrz nad mistrze - ksiądz profesor Stanisław Librowski, s. 73.

${ }^{71}$ Tamże, s. 74. Potwierdzeniem tej opinii może być fakt, że ks. prof. S. Librowski nigdy nie zatrudnił po rezygnacji ks. L. Grzebienia swojego ucznia jako asystenta naukowego.

${ }^{72}$ Ze względu na brak dokumentacji w redakcji ABMK, nie wiemy, czy ks. L. Grzebień przesłał jakiś swój artykuł.

${ }^{73}$ Ks. S. Librowski zwrócił się do czterech swoich uczniów: ks. dr Ludwika Grzebienia (jezuity w Krakowie); ks. mgr. Feliksa Lenorta (Poznań); ks. dr Romana Nira (Częstochowa); o. dr. Janusza Zbudniewka (paulina w Krakowie). Zob. Librowski, Kalendarium życia, s. 523.

${ }^{74}$ Dokumenty swoich uczniów złożył ks. S. Librowski 25 maja 1978 r. na ręce ks. doc. dr hab. Józefa Krukowskiego, przewodniczącego Wydziału Teologiczno-Kanonicznego Towarzystwa Na- 
Relacja ta znajduje potwierdzenie również we wspomnieniach ks. L. Grzebienia, który po rezygnacji z etatu w KUL i podjęciu stałej pracy naukowej w jezuickim ośrodku naukowym w Krakowie nadal utrzymywał kontakty naukowe, choć rzadkie z ks. S. Librowskim. Spotkania te zawsze miały charakter „miłych wydarzeń"75. Współpracę ze środowiskiem naukowym KUL ks. L. Grzebień utrzymywał poprzez redakcję „Encyklopedii Katolickiej”, do której przygotowywał hasła dotyczące jezuitów ${ }^{76}$.

Jak wspominał ks. L. Grzebień, w swoim życiu naukowym naśladował działalność ks. S. Librowskiego nie tylko w dydaktyce czy redakcji, ale również przy tworzeniu własnego jezuickiego ośrodka badawczego w Krakowie na wzór Ośrodka Archiwów, Bibliotek i Muzeów Kościelnych KUL ${ }^{77}$. Jak wiadomo ks. L. Grzebień działania te zwieńczył sukcesem, gdyż nie tylko przekształcił jezuicki Wydział Filozoficzny w Wyższą Szkołę Filozoficzno-Pedagogiczną „Ignatianum” (dziś: Akademia Ignatianum) gdzie pełnił funkcję Rektora, ale zreorganizował też Archiwum Prowincji Polski Południowej Towarzystwa Jezusowego w Krakowie i Bibliotekę Naukową Jezuitów, wzbogacając je o nowe zbiory, przez co stały się one warsztatem pracy nie tylko dla niego, ale i jego uczniów-współbraci jezuitów i świeckich ${ }^{78}$.

Podsumowaniem artykułu może być cytat ze wspomnień ks. L. Grzebienia:

Choć miałem w życiu kilku podobnych mistrzów, to jednak dzięki księdzu Librowskiemu zrozumiałem wagę i metody badań źródłowych we wszystkich aspektach historii Kościoła. W całej mojej działalności naukowej duchowym przewodnikiem jest ksiądz profesor Stanisław Librowski - mistrz nad mistrze ${ }^{79}$.

\section{BIBLIOGRAFIA}

\section{Źródła}

Archiwum Uniwersyteckie KUL (AUKUL),

sygn. A-1148, Referat Personalny, Akta osobowe pracowników, Grzebień Ludwik ks. (1972-1974).

Grzebień Ludwik, Mistrz nad mistrzami - ksiadz profesor Stanisław Librowski, w: Ksiadz Stanisław Librowski. Archiwista, historyk Kościoła i dydaktyk, red. W. Żurek, D. Kiper, Lublin 2015, s. 69-75.

ukowego KUL. W dniu 2 maja zostali wybrani na członków wspomnianego Wydziału. Pod koniec czerwca otrzymali oni stosowne dyplomy. Librowski, Kalendarium życia, s. 523.

${ }^{75}$ Grzebień, Mistrz nad mistrze - ksiądz profesor Stanisław Liberowski, s. 75.

${ }^{76}$ Bieś, Bibliografia prac, s. 33-76.

${ }^{77}$ Grzebień, Jezuicki ośrodek badań historycznych w Krakowie, s. 35-56.

${ }^{78}$ Terlecki, Pasja historyka. Ojca Ludwika Grzebienia życie i praca, s. 20; Grzebień, Jezuicki ośrodek badań historycznych w Krakowie, s. 36-56; Cieślak, Jubileusz o. Ludwika Grzebienia SJ, s. 127.

${ }^{79}$ Grzebień, Mistrz nad mistrze - ksiądz profesor Stanisław Librowski, s. 75. 


\section{Opracowania}

Bieś Andrzej P. (red.), Bibliografia prac Księdza Profesora Ludwika Grzebienia SJ za lata 1962-2009, w: Pamięć wieków kształtuje potomność. Księga jubileuszowa dedykowana księdzu Ludwikowi Grzebieniowi SJ z okazji 70. urodzin, Kraków 2010, s. 33-76.

Bohonos Maria, Szandorowska Elisa, Spandowski Michael, Kawecka-Gryczowa Alodia, Incunabula quae in bibliothecis Poloniae asservantur. 2, Addenda, indices, Wrocław 1994.

Buchwald-Pelcowa Paulina, Wkład Profesor Alodii Kaweckiej-Gryczowej w rozwój nauki o książce, „Z badań nad książka i księgozbiorami historycznymi”, 5 (2011) s. 15-26.

Cieślak Stanisław, Jubileusz o. Ludwika Grzebienia SJ, „Biuletyn Historii Wychowania”, 26 (2010) s. 121-130.

Dębowska Maria, Wkład księdza profesora Stanisława Librowskiego w powstanie, organizację i realizację zadań statutowych Ośrodka Archiwów Bibliotek i Muzeów Kościelnych, „Studia Włocławskie”, 10 (2007) s. 53-61.

Grzebień Ludwik, Katalog starych druków Biblioteki Teologicznej Bobolanom (Polonica XVI w.), „Archiwa, Biblioteki i Muzea Kościelne”, 16 (1968) s. 243-278.

Grzebień Ludwik, Uzupetnienia do Bibliografii Estreicherów z Biblioteki Teologicznej Bobolanum w Warszawie, „Archiwa, Biblioteki i Muzea Kościelne”, 19 (1969) s. $45-80$.

Grzebień Ludwik, Duchowieństwo polskiego odrodzenia a ksiązka. Na marginesie czterech książek o bibliotekach personalnych, „Archiwa, Biblioteki i Muzea Kościelne”, 21 (1970) s. 295-300.

Grzebień Ludwik, Biblioteka biskupa Hieronima Rozrażewskiego (1542-1600), „Archiwa, Biblioteki i Muzea Kościelne”, 22 (1971) s. 61-168.

Grzebień L., Lisikiewicz Józef, w: Polski Stownik Biograficzny, t. 17, red. E. Rostworowski, Wrocław 1972, s. 461-462.

Grzebień Ludwik, Słowniczek ważniejszych pisarzy jezuitów, w: Wydawnictwo Apostolstwo Modlitwy 1872-1972. Historia, opracowania, bibliografia, Kraków 1972, s. 199-216.

Grzebień Ludwik, Stulecie wydawnictwa jezuickiego w Krakowie, „Archiwa, Biblioteki i Muzea Kościelne”, 25 (1972) s. 229-237.

Grzebień Ludwik, Wilkosz Zofia, Bibliografia retrospektywna wydawnictw własnych i przejętych /WAM/, Kraków 1972.

Grzebień Ludwik, Wilkosz Zofia, Wydawnictwo Apostolstwo Modlitwy 1872-1972. Historia, opracowania, bibliografia, Kraków 1972.

Grzebień Ludwik, Organizacja bibliotek jezuickich w Polsce od XVI do XVIII wieku (I), „Archiwa, Biblioteki i Muzea Kościelne”, 30 (1975) s. 223-278.

Grzebień Ludwik, Organizacja bibliotek jezuickich w Polsce od XVI do XVIII wieku (II), „Archiwa, Biblioteki i Muzea Kościelne”, 31 (1975) s. 225-281.

Grzebień Ludwik (red.), Wydziat Teologiczny „Bobolanum”, w: „Encyklopedia wiedzy o jezuitach na ziemiach Polski i Litwy 1564-1995, Kraków 1996, s. 771.

Grzebień Ludwik, Wilkosz Zofia, Wydawnictwo WAM 1972-1997. Historia, bibliografia, Karków 1997.

Grzebień Ludwik, Organizacja bibliotek jezuickich w Polsce od XVI do XVIII wieku, Kraków 2013.

Hajdukiewicz Leszek, Biblioteka Macieja z Miechowa, Wrocław 1960.

Hajdukiewicz Leszek, Ksiegozbiór i zainteresowania bibliofilskie Piotra Tomickiego na tle jego działalności kulturalnej, Wrocław 1961.

Jezuicka ars historica: prace ofiarowane Księdzu Profesorowi Ludwikowi Grzebieniowi SJ, red. M. Inglot, S. Obirek, Kraków 2001. 
Kawecka-Gryczowa Alodia, Bohonos Maria, Szandrowska Elisa, Incunabula quae in bibliothecis Poloniae esservantur/ Inkunabuły w bibliotekach polskich. Centralny kata$\log$, t. 1-2, Wrocław 1970.

Korotajowa Krystyna, Alodia Kawecka-Gryczowa 11 VIII 1903 - 16 VI 1990, „Biuletyn Polonistyczny", 4 (1991) nr 3-4 (122-123), s. 184-191.

Krahel Tadeusz, Schematyzmy Diecezji Wileńskiej jako źródło historyczne (I), „Archiwa, Biblioteki i Muzea Kościelne”, 38 (1979) s. 109-149.

Krahel Tadeusz, Schematyzmy Diecezji Wileńskiej jako źródło historyczne (II), „Archiwa, Biblioteki i Muzea Kościelne”, 39 (1979) s. 191-235.

Kubiak Barbara, Ludwik Grzebień SJ, Organizacja bibliotek jezuickich w Polsce od XVI do XVIII wieku, Kraków 2013, 250 stron, „Studia Podlaskie”, 21 (2013) s. 397-399.

Kujawski Witold, Ks. prof. Stanisław Librowski. Archiwista, historyk, redaktor, „Studia Włocławskie", 2 (1999) s. 7-17.

Lewicka-Kamińska Anna, Renesansowy księgozbiór Mikołaja Czepla w Bibliotece Jagiellońskiej, Wrocław 1956.

Librowski Stanisław, Dwadzieścia pięć tomów czasopisma „Archiwa, Biblioteki i Muzea Kościelne”, „Archiwa, Biblioteki i Muzea Kościelne”, 25 (1972) s. 5-38.

Librowski Stanisław, Kalendarium życia, cierpień, działalności, twórczości i uznania księdza Stanisława Librowskiego. Dokończenie, „Archiwa, Biblioteki i Muzea Kościelne", 59 (1990) s. 405-599.

Różański Zdzisław, Księgi liturgiczne Biblioteki Seminarium Duchownego we Włocławku. Studium liturgiczno-źródłoznawcze, „Archiwa, Biblioteki i Muzea Kościelne”, 42 (1981) s. 59-149.

Rulka Kazimierz, Stan badań nad księgozbiorami Diecezji Włocławskiej oraz postulaty badawcze na przyszłość, „Archiwa, Biblioteki i Muzea Kościelne”, 26 (1973) s. 5-57.

Soliński Krzysztof, Katalog poloników w Biblioteca Universitaria Alessandrina, Warszawa 2014.

Soliński Krzysztof, Katalog poloników w Biblioteca Casanatense, Warszawa 2016.

Soliński Krzysztof, Katalog starodruków biblioteki Papieskiego Instytutu Studiów Kościelnych w Rzymie, Warszawa 2016.

Soliński Krzysztof, Katalog poloników w Biblioteca dell'Accademia Nazionale dei Linceie Corsiniana, Warszawa 2019.

Spandowski Michał, Katalog starych druków biblioteki Papieskiego Kolegium Polskiego w Rzymie, Warszawa 2010.

Spandowski Michał, Pludra-Żuk Paulina, Katalog poloników biblioteki Pontificia Università Urbaniana, Warszawa 2012.

Szelińska Wacława, Biblioteki profesorów Uniwersytetu Krakowskiego w XV i początkach XVI wieku, Wrocław 1966.

Sztafrowski Edward, Śp. ks. prof. Marian Aleksander Żurowski SJ, „Prawo Kanoniczne”, 34 (1991) nr 1-2, s. 5-12.

Terlecki Ryszard, Pasja historyka. Ojca Ludwika Grzebienia życie i praca, w: Pamięć wieków ksztattuje potomność. Księga jubileuszowa dedykowana Księdzu Profesorowi Ludwikowi Grzebieniowi SJ z okazji 70. urodzin, red. A.P. Bieś, B. Topij-Stempińska, Kraków 2010, s. 17-22.

Walkusz Jan, Sekcja Historii Kościoła w Polsce 1964-2014, Pelplin 2016, s. 155-156.

Weiss Anzelm, Ksiadz profesor Stanisław Librowski jako nauczyciel akademicki, w: Ksiadz Stanisław Librowski archiwista, historyk Kościoła i dydaktyk, red. W. Żurek, D. Kiper, Lublin 2015, s. 103-109. 
Zahajkiewicz Marek, Ksiadz profesor dr hab. Stanisław Librowski (1914-2002), badacz przeszłości i uczony zastużony dla archiwistyki kościelnej, „Archiwa, Biblioteki i Muzea Kościelne", 79 (2003) s. 13-18.

Zahajkiewicz Marek, Librowski Stanisław, w: Encyklopedia katolicka, t. 10, red. E. Ziemann, Lublin 2004, kol. 985-986.

Zbudniewek Janusz H., Kopiarz dokumentów konwentu Paulinów w Wieruszowie (I), „Archiwa, Biblioteki i Muzea Kościelne”, 26 (1973) s. 199-261;

Zbudniewek Janusz H., Kopiarz dokumentów konwentu Paulinów w Wieruszowie. Część 2: Treść dokumentów kopiarza, „Archiwa, Biblioteki i Muzea Kościelne”, 27 (1973) s. $207-260$.

\section{Netografia}

Elektroniczna Baza Bibliografii Estreichera (EBBE), https://www.estreicher.uj.edu.pl/ home/ (dostęp: 02.04.2020).

Cieślak Stanisław SJ, Odszedt do Pana śp. o. Ludwik Grzebień SJ-wspomnienie, https:// jezuici.pl/2020/03/odszedl-do-pana-sp-o-ludwik-grzebien-sj/ (dostęp: 02.04.2020).

Grzebień Ludwik, https://www.jezuici.krakow.pl/cgi-bin/rjbo?b=enc\&q=GRZEBIEN\&f=1 (dostęp: 02.04.2020).

\section{REV. LUDWIK GRZEBIEŃ SI (1939-2020) \\ - A STUDENT AND SCIENTIFIC ASSISTANT OF REV. PROF. STANISŁAW LIBROWSKI}

\section{Summary}

Rev. Ludwik Grzebień, SJ was a student and then the scientific assistant of Rev. Prof. Stanisław Librowski. Their cooperation began in 1968 when Rev. L. Grzebień's scientific papers were published. In the same year he began studying at the Institute of Church History, attending Rev. S. Librowski's seminars. In 1970, Rev. L. Grzebień presented his Master's dissertation entitled 'Biblioteka biskupa Hieronima Rozrażewskiego' (The Library of Bishop Hieronim Rozrażewski) (1542-1600). Just a year after obtaining his master's degree (1971), he submitted a dissertation entitled 'Organization of Jesuit libraries in Poland from 16th to 18th century'. Both papers received very good reviews. After defending his doctorate in 1972, Rev. L. Grzebień was offered a position of scientific assistant in the Department of Auxiliary Sciences of History and Methodology of History by Rev. S. Librowski . During his research work in the Catholic University of Lublin, he was distinguished by great scientific diligence. In the academic year 1972/1973, he published five scientific articles. In August 1973, Rev. L. Grzebień travelled to England for a language course, archival research and for the purposes of the next stage of religious formation. He did not return to KUL, devoting himself instead to the realization of his scientific plans connected with the Jesuit order.

Keywords: Rev. Ludwik Grzebień; Rev. Stanisław Librowski; Ignatianum; Jesuits; Catholic University of Lublin 